\title{
Microbial Quality of Raw Beef and Chevon From Selected Markets in Cape Coast, Ghana
}

\author{
Levi Yafetto (Corresponding Author)
}

Department of Molecular Biology and Biotechnology, School of Biological Sciences, College of Agriculture and Natural Sciences, University of Cape Coast, Cape Coast, Ghana,

E-mail: lyafetto@ucc.edu.gh

Emelia Hornam Adator

Department of Food and Human Nutritional Sciences, Faculty of Agricultural and Food Sciences, University of Manitoba, Winnipeg, MB R3T 2N2, Canada

Abena Ahema Ebuako

Department of Molecular Biology and Biotechnology, School of Biological Sciences, College of Agriculture and Natural Sciences, University of Cape Coast, Cape Coast, Ghana

Ephraim Ekloh

Department of Molecular Biology and Biotechnology, School of Biological Sciences, College of Agriculture and Natural Sciences, University of Cape Coast, Cape Coast, Ghana

Francis Yao Afeti

Department of Molecular Biology and Biotechnology, School of Biological Sciences, College of Agriculture and Natural Sciences, University of Cape Coast, Cape Coast, Ghana

Received: December 10, 2018 Accepted: January 15, 2019

doi:10.5296/jbls.v10i1.14022ＵRL: https://doi.org/10.5296/jbls.v10i1.14022

\begin{abstract}
This study assessed microbial quality of raw beef and chevon (goat meat) from selected meat retail shops in Abura, Kotokuraba and Science markets in Cape Coast, Ghana. Stock solutions from beef and chevon were analyzed on nutrient agar, MacConkey agar, and potato dextrose agar media using microbiological procedures. Results revealed that beef from Kotokuraba market was the most contaminated with mean highest bacterial counts of $1.15 \times 10^{8}$ and $9.40 \times 10^{7} \mathrm{cfu} / \mathrm{ml}$ in nutrient agar and MacConkey agar media, respectively. The results further showed that chevon from Science market was the most contaminated with mean highest bacterial counts of $1.67 \times 10^{8}$ and $7.10 \times 10^{7} \mathrm{cfu} / \mathrm{ml}$ in nutrient agar and MacConkey agar media, respectively. Mean fungal counts in PDA medium was the least recorded for both beef and
\end{abstract}


chevon from all the three markets. Comparative analyses of results suggest that chevon was more contaminated than beef from Abura market, whereas beef was more contaminated than chevon from Kotokuraba market. However, from Science market, except in MacConkey agar medium, where beef was more contaminated than chevon, chevon was more contaminated than beef in nutrient agar and PDA media. Bacteria isolated were Escherichia coli, Klebsiella spp., Nocardia spp., Salmonella spp., Staphylococcus spp., and Streptococcus spp. Fungi of the genera Aspergillus, Candida, Fusarium, Penicillium, and Rhodotorula were isolated. We conclude that raw beef and chevon sold in markets in Cape Coast are contaminated by pathogenic and toxigenic microbes that may affect meat quality and consequently pose public health concerns to consumers.

Keywords: beef, Cape Coast, chevon, foodborne illness, food microbiology, Ghana, microbial contamination

\section{Introduction}

Food consumers all over the world desire quality nutritious, healthy foods that are of good quality, have long shelf-life, and are convenient to prepare (Huang et al., 2014). This desire to have nutritious, healthy foods is vital in a world challenged with limited resources and increasing global population (Bryan, 1977).

Meat, one of the most important foods consumed worldwide, is an excellent source of animal protein in human diet (Huang, et al., 2014). Because of its high amino acids and protein contents, and especially vitamin B12, which is not available in plant sources, meat is consumed globally by many people (Ateba \& Setona, 2011; Bradeeba \& Sivakumaar, 2012; Eaton \& Konner, 1985; Stufflebeam, 1983). The rich nutritive content of meat makes it susceptible to microbial contamination, since it promotes growth and multiplication of microorganisms. Contaminated meats are, thus, rendered perishable, if not properly handled and preserved (Huda et al., 2010; Steinkraus, 1994; Subratty \& Gurib, 2003). Microbial contamination of meat is a major cause of food poisoning and foodborne illnesses worldwide (Nel et al., 2004; Yousuf et al., 2008). An estimated 9.4 million illnesses are caused from foodborne diseases by known pathogens each year in the United States (Scallan et al., 2011). Expectedly, according to the Centers for Disease Control and Prevention, in 2016, there were a reported 839 cases of foodborne disease outbreaks that resulted in 14,259 illnesses, 875 hospitalizations, 17 deaths, and 18 food product recalls (CDC, 2016). Also, the World Health Organization reported that 600 million foodborne illnesses caused 420, 000 deaths in 2010 globally (WHO, 2015).

The high incidence of foodborne illnesses, with their resultant economic consequences, are common in developing countries and it is commonly associated with foods from animals (Kivi et al., 2007; Koffi-Nevry et al., 2011). These foodborne illnesses associated with food from animals suggest that, indeed, if animals are slaughtered and the meats are not immediately utilized or preserved properly, over time, they become unwholesome due to activities of microbes present (Koffi-Nevry et al., 2011). But because microorganisms are always associated with slaughtered animals, it has become public health concern that meat products on the Ghanaian market may not be wholesome. To this end, beef and chevon, two 
of the most popular meats consumed in Ghana, are not spared the scrutiny that Ghanaian consumers always subject meat products to, whether raw, frozen, smoked or salted. It is publicly acknowledged that meat in Ghana is largely produced under unhygienic conditions and practices such as (i) dressing of carcasses on the floor and concrete slabs of slaughterhouses, (ii) the use of unclean water to wash carcasses, and (iii) insufficient pre- and post-slaughter inspections (Bryan 1977; Mahaboubil-Haq \& Adzitey, 2016).

In Ghana, raw beef, chevon, chicken, guinea fowl, mutton, pork, etc., are mostly patronized in large quantities throughout the year, especially during Christian and Islamic religious festivities. It is suggested that about 60,000 street food vendors sell an estimated $\$ 100$ million worth of street-vended food annually in Accra, the capital of Ghana; these street food vendors are supplied with beef by butchers at the abattoirs and meat retail shops (King et al., 2000; Tomlins et al., 2002). The significantly high demand for meat may be due to a decline in the consumption of chicken products (Hobbs \& Roberts, 1993).

There is good number of literature on microbial quality of meat and street-vended foods mostly in Northern and Greater Accra regions of Ghana (Ababio \& Lovatt, 2015; Adejunmobi, 2015; Adu-Gyamfi et al. 2012; Adzitey et al., 2010; Adzitey et al., 2011a; Adzitey et al., 2011b; Adzitey, 2013; Adzitey et al., 2014; Annan-Prah, et al., 2011; FAO, 2016; Kutah, 2010; Mahaboubil-Haq \& Adzitey, 2016; Mensah et al., 2001; Obeng et al., 2013; Soriyi et al., 2008; Twum, 2015; Yeboah-Manu et al., 2010; Yeleliere et al., 2017). Unfortunately, there are few studies on microbial quality of meat and street foods in Cape Coast, Ghana (Adejunmobi, 2015; Annan-Prah, et al. 2011). This revelation of scant literature was borne out of extensive literature search aimed to finding accounts of studies of microbial quality of meat in Cape Coast. This search only turned out two studies by Annan-Prah, et al. (2011), and Annor-Frimpong and Danquah (1994), who studied microbial quality of street foods and meat consumption pattern, respectively. Meanwhile, Adejunmobi (2015) conducted a preliminary study on the microbial quality of meat from the popular Kotokoraba market in Cape Coast, which findings provided an impetus for this broader study. To this end, we aimed to investigate the microbial quality of beef and chevon sold in meat retail shops from selected markets in the Cape Coast, Ghana. This paper presents the findings from this study and recommends strategies to improving wholesomeness of meat products obtained from butchers at the abattoirs, retailers at meat retail shops, through to street-food vendors and domestic consumers.

\section{Materials and Methods}

\subsection{Chemicals, Equipment and Culture Media}

Chemicals and reagents used were of analytical grade. Microbiological culture media used in the study were from Oxoid (Oxoid Ltd., England). Equipment used were platform shaker (Scientific Industries, Inc., USA); Autoclave (Shimadzu KY-23D, Omron Corporation, Japan); Water bath (Grant JB Series, England); Incubator (Plus II, Gallenkamp, England); Leica DM500 Compound Microscope (Leica Microsystems, Switzerland); Lamina Flow Hood (Edge GARD, The Baker Company, USA) and Digital colony counter (Stuart Scientific, UK). 


\subsection{Study Design}

This study was a laboratory-based research. It was designed to (i) isolate microbes from beef and chevon, (ii) determine the extent of microbial contamination by enumeration of bacterial and fungal contaminants and (iii) identify and confirm the bacterial and fungal species that had contaminated the meat products (Figure 1).

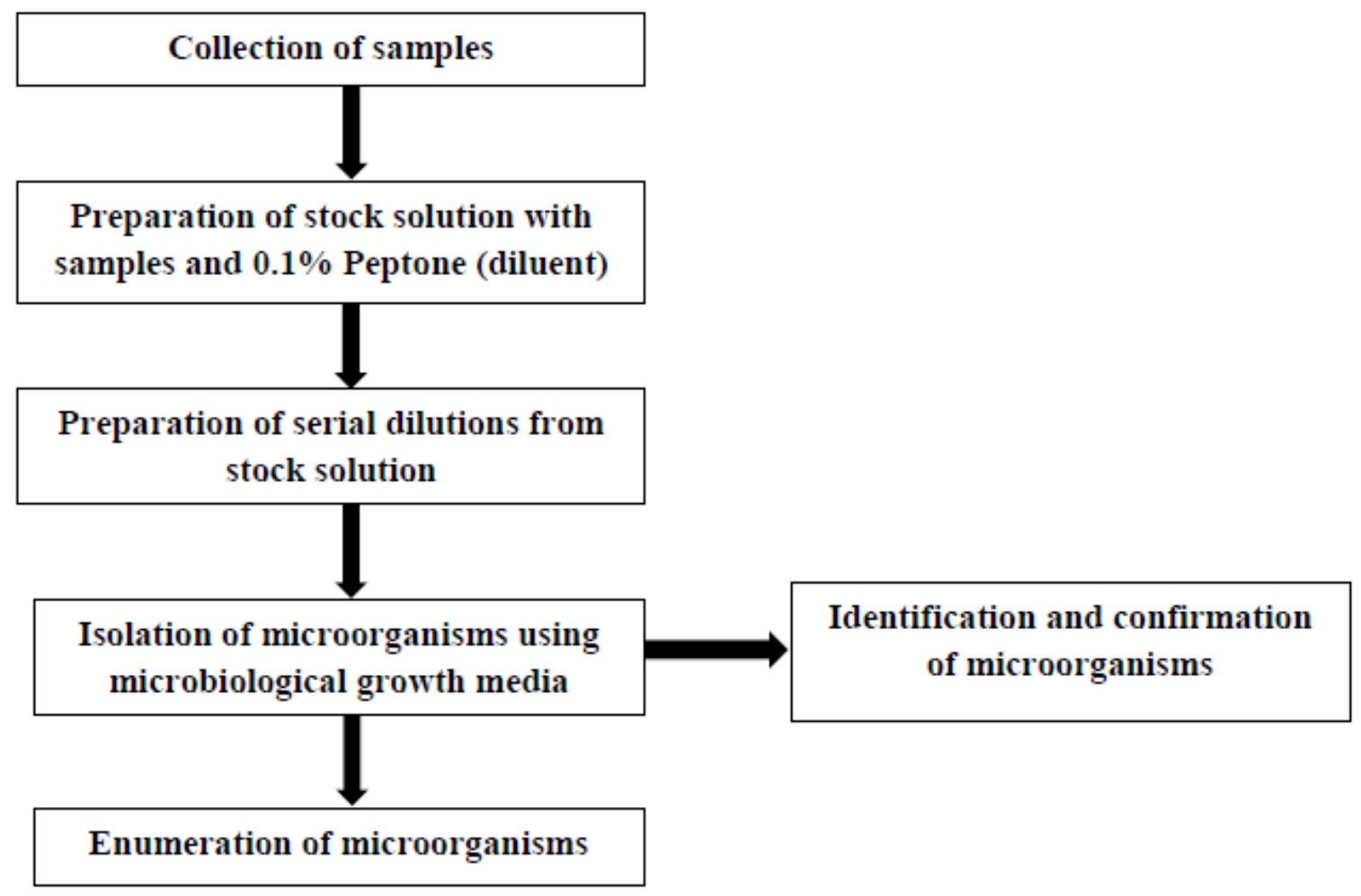

Figure 1. Schematic flow chart of research design used in this study

\subsection{Study Area}

This study was carried out in Cape Coast, Ghana. According to the 2010 Population and Housing Census in Ghana, Cape Coast ( $5^{\circ} 7$ '53.44" North, $1^{\circ} 16^{\prime} 53.11^{\prime \prime}$ West) has a settlement population of 169,894 people. Major economic activities of the people of Cape Coast are farming (plant cropping and animal breeding), fishing and petty trading. Cape Coast is a historic, prominent, popular tourism destination for both domestic and foreign tourists, and it continues to enjoy an enviable status as one of the most important tourism destinations in Ghana (Ghana Statistical Services, 2010). Cape Coast is also highly regarded as the citadel of education in Ghana, because it boasts some of the finest second-cycle and tertiary educational institutions in the country. The Cape Coast Castle, which played a critical role as a slave post in the Trans-Atlantic Slave Trade in the $15^{\text {th }}$ century is a designated world heritage site by the United Nations Educational, Scientific and Cultural Organization (Yafetto \& Osei-Bonsu, 2017). Two meat retail shops were selected randomly from three major markets in Cape Coast to obtain raw beef and chevon for the study. The three markets are Abura, Kotokokuraba, and Science markets, all located in the populous southern suburbs of Cape Coast. Specifically, Abura market serves mainly suburbs such as Adisadel, Akotokyir, 


\section{Macrothink}

Kakomdo, Pedu, and the Technical University of Cape Coast and University of Cape Coast (UCC). Kotokuraba is the largest, central market, hence serves almost all the suburbs in Southern Cape Coast. The Science market is located at the University of Cape Coast and serves mostly student, staff and some of the surrounding communities such as Amamoma, Apewosika, and Kwaprow (Figure 2).

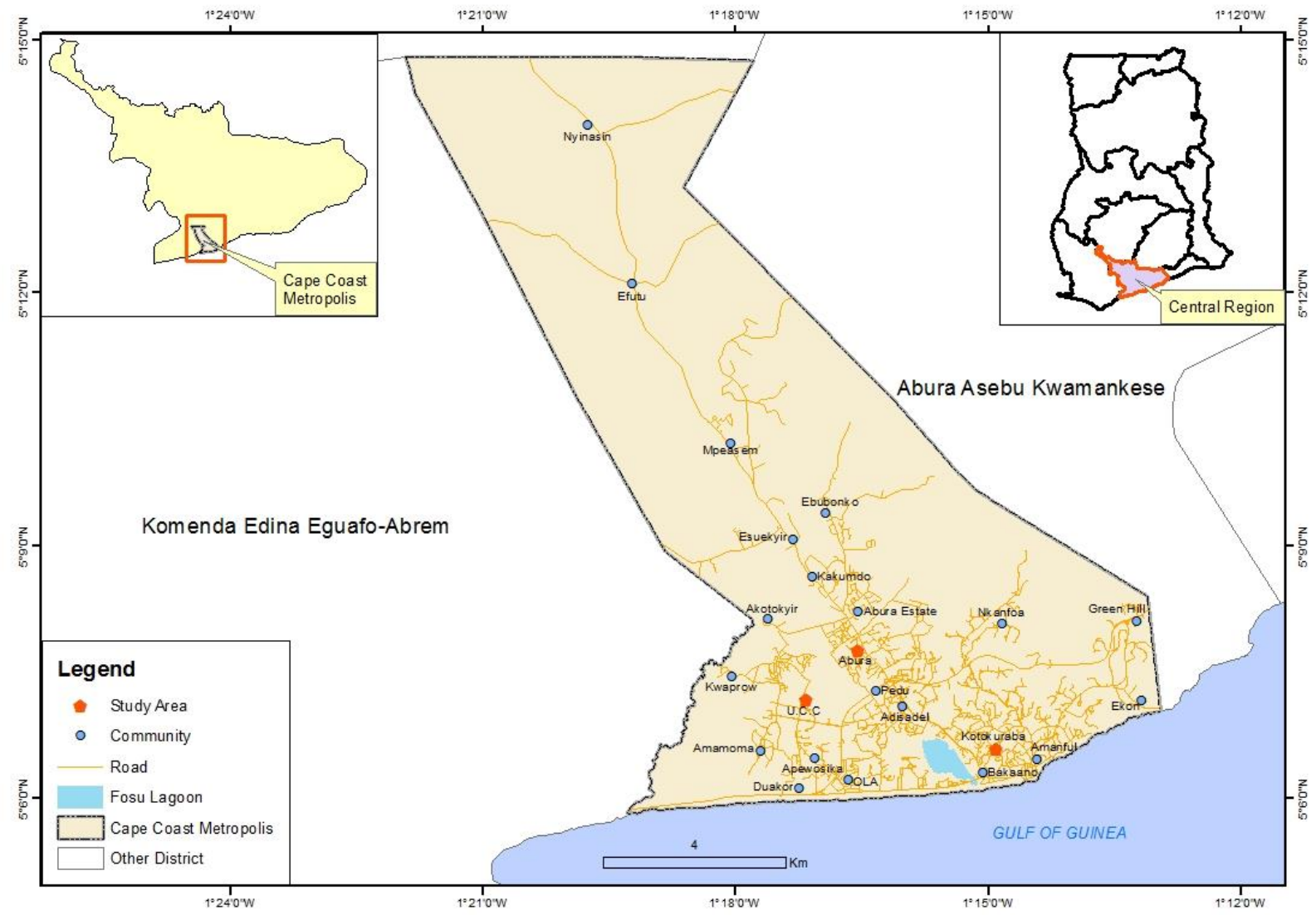

Figure 2. Cape Coast indicating three major markets where beef and chevon were obtained for the study. Source: Richard Adade, Centre for Coastal Management, University of Cape Coast, Cape Coast, Ghana

\subsection{Sample Collection}

A quantity of $1 \mathrm{lbs}$. each of raw beef and chevon was purchased from two randomly selected meat retail shops in Abura, Kotokoraba and Science markets in Cape Coast. The carcasses of the meats were separately packaged in appropriately labeled, sealed zip-locks, placed in an ice chest, and immediately transported to the laboratory for microbial analyses using standard microbiological procedures. Observations of pre- and post-butchering practices by the butchers and retailers at the abattoirs and meat retail shops including frequent cleaning of benches, weighing scales and knives, use of aprons, wearing of hair coverings, proper handling of money, use of gloves while serving, etc. were made during purchase. 


\subsection{Culture Media}

\subsubsection{Potato Dextrose Agar}

A quantity of $39 \mathrm{~g}$ of PDA powder was dissolved in $1 \mathrm{~L}$ distilled water, supplemented with 250 $\mathrm{mg}$ of chloramphenicol, and autoclaved at $1.1 \mathrm{~kg} / \mathrm{cm}^{2}$ at $121^{\circ} \mathrm{C}$ for 15 minutes. The PDA medium was then supplemented with $250 \mathrm{mg}$ of chloramphenicol, and thoroughly mixed, after which approximately $20 \mathrm{ml}$ aliquots were dispensed into sterile Petri dishes. The plates were then allowed to solidify and stored until ready to use.

\subsubsection{MacConkey Agar}

A quantity of $49.53 \mathrm{~g}$ of dehydrated MacConkey agar powder was suspended in $1 \mathrm{~L}$ distilled water, and thoroughly stirred to obtain a uniform mixture, which was then heated to boiling to completely dissolve the medium. The medium was autoclaved at $1.1 \mathrm{~kg} / \mathrm{cm}^{2}$ at $121^{\circ} \mathrm{C}$ for 15 minutes, left to cool to $40-45^{\circ} \mathrm{C}$, dispensed in approximately $20 \mathrm{ml}$ aliquots into sterile Petri dishes and allowed to solidify prior to use.

\subsubsection{Nutrient Agar}

A quantity of $28 \mathrm{~g}$ of nutrient agar powder was suspended in $1 \mathrm{~L}$ distilled water, and thoroughly stirred to obtain a uniform mixture. The mixture was then heated to boiling to completely dissolve the medium. The medium was autoclaved at $1.1 \mathrm{~kg} / \mathrm{cm}^{2}$ at $121^{\circ} \mathrm{C}$ for 15 minutes, left to cool to $40-45^{\circ} \mathrm{C}$, dispensed into sterile Petri dishes and allowed to solidify prior to use.

\subsection{Stock Solution from Beef and Chevon}

Ten grams of raw beef was weighed, chopped into small pieces and placed in $90 \mathrm{ml}$ sterile $0.1 \%$ peptone water (the diluent) in a $200 \mathrm{ml}$ conical flask. The chopped beef and diluent were thoroughly vortexed on a platform shaker for 5 minutes to wash off and dislodge any microbe that may be resident on the surface of the chopped beef. The diluent was decanted and used as a stock solution to prepare serial dilutions for microbiological analyses. Serially diluted stock solution of dilution factor $10^{-3}$ was used for fungal isolation; serially diluted stock solution of dilution factor $10^{-6}$ was used for bacterial isolation. This procedure was repeated for the preparation of stock solution from chevon.

\subsection{Isolation of Microbes}

For fungal isolation, $1 \mathrm{ml}$ aliquot of stock solution of beef with dilution factor $10^{-3}$ was dispensed into a Petri dish, after which $20 \mathrm{ml}$ molten, but cooled PDA medium was added and swirled clockwise and anticlockwise to ensure the stock solution was evenly distributed in the medium. The culture plates were prepared for the two samples obtained for beef from the three markets (i.e., $\mathrm{n}=6$ ), allowed to solidify and incubated at $25^{\circ} \mathrm{C}$ for 7 days. This isolation procedure was repeated for the microbiological analyses of chevon.

For bacterial isolation, the same procedure used to isolate fungi was employed, except that $1 \mathrm{ml}$ stock solution of beef with dilution factor $10^{-6}$ was dispensed separately into $20 \mathrm{ml}$ of molten MacConkey agar and $20 \mathrm{ml}$ of molten nutrient agar. The culture plates were prepared for the two samples obtained for beef from the three markets (i.e., $n=6$ for MacConkey agar; $n=6$ for 
nutrient agar), allowed to solidify and incubated at $37^{\circ} \mathrm{C}$ for 2 days. This isolation procedure was repeated for the microbiological analyses of chevon.

\subsection{Colony Counts and Statistical Analyses}

All the results of bacterial and fungal colonies were enumerated with digital colony counter and expressed as mean colony counts ( \pm Standard Deviation), mean colony forming units per $\mathrm{ml}(\mathrm{cfu} / \mathrm{ml})$ and mean $\log _{10} \mathrm{cfu} / \mathrm{ml}$, where $\mathrm{n}=6$. Differences in the means were statistically analyzed using ANOVA at confidence level of $95 \%$ ( $\mathrm{p}<0.05)$.

\subsection{Identification of Bacteria and Fungi}

A small section of fungal sample was carefully removed from a fungal colony with an inoculation needle and immersed in a drop of $70 \%$ of alcohol on a glass slide. The fungal sample was gently teased out with the inoculation needle, after which a drop of lactophenol cotton blue dye was added to the fungal sample and gently covered with a glass coverslip. Excess dye was removed with a Whatman filter paper (Sigma-Aldrich, USA). The fungal specimen, thus prepared, was then observed under the microscope. Microscopic identifications of fungi were based on morphological and growth features in consultations with the relevant identification manuals (Barnett \& Hunter, 1995; Campbell et al., 2013; Courtecuisse \& Duhem, 1995; Ellis et al., 2007; Gilbertson \& Ryvarden, 1986; Kidd, et al., 2016; Læssøe, 1998; Overholts, 1953; Pegler, 1977; Phillips, 1981; Pitt \& Hocking, 2009; Ryvarden \& Johnsen, 1980; van der Westhuizen \& Eicker, 1994; Watanabe, 2010). Images of fungal cultures were captured with an in-built, 8 megapixels digital camera of an iPhone $5 \mathrm{~s}$ (Apple Company, California, USA).

Bacteria were sub-cultured to obtain pure cultures and their identity further confirmed using morphological characteristics and other methods according to Adzitey et al. (2010), Annan-Prah et al. (2011), and Obeng et al. (2013).

\section{Results}

\subsection{Bacterial and Fungal Counts of Beef}

Beef from Kotokuraba market was the most contaminated with mean highest bacterial counts of $1.15 \times 10^{8}$ and $9.40 \times 10^{7} \mathrm{cfu} / \mathrm{ml}$ in nutrient agar and MacConkey agar media, respectively, and mean highest fungal counts of $1.60 \times 10^{4} \mathrm{cfu} / \mathrm{ml}$ in PDA. This was followed by microbial counts from beef from Science market, with mean bacterial counts of $1.05 \times 10^{8}$ and $7.80 \times 10^{7}$ $\mathrm{cfu} / \mathrm{ml}$ in nutrient agar and MacConkey agar, respectively, and mean fungal counts of $2.00 \times 10^{3}$ in PDA, which was incidentally the mean lowest fungal count compared to mean fungal counts from Abura and Kotokuraba markets. Interestingly, beef from Abura markets had the mean lowest bacterial counts of $4.50 \times 10^{7}$ and $1.90 \times 10^{7} \mathrm{cfu} / \mathrm{ml}$ in nutrient agar and MacConkey agar, respectively (Table 1).

\subsection{Bacterial and Fungal Counts of Chevon}

Chevon from Science market was the most contaminated with mean highest bacterial counts of $1.67 \times 10^{8}$ and $7.10 \times 10^{7} \mathrm{cfu} / \mathrm{ml}$ in nutrient agar and MacConkey agar media, respectively, 
and mean fungal counts of $4.30 \times 10^{4} \mathrm{cfu} / \mathrm{ml}$ in PDA medium. Chevon from Abura market was the least contaminated with mean lowest bacterial counts of $8.80 \times 10^{7}$ and $4.00 \times 10^{7} \mathrm{cfu} / \mathrm{ml}$ in nutrient agar and MacConkey agar media, respectively. Incidentally the mean highest fungal counts of $4.40 \times 10^{4} \mathrm{cfu} / \mathrm{ml}$ were recorded for chevon obtained from Abura market, whereas the mean lowest fugal counts of $1.00 \times 10^{3} \mathrm{cfu} / \mathrm{ml}$ were recorded for chevon obtained from Kotokoraba market in PDA medium (Table 2).

Overall, comparative analyses of results revealed that (i) chevon was more contaminated than beef at Abura market and (ii) beef was more contaminated than chevon at Kotokuraba market. However, at Science market, except in MacConkey agar medium, where beef was more contaminated than chevon, chevon was more contaminated in nutrient agar and PDA media than beef (Table 1 and Table 2).

Results of bacterial and fungal colony counts of beef and chevon are presented graphically as mean $\log 10 \mathrm{cfu} / \mathrm{ml}$ (Figure 3 and Figure 4).

Table 1. Mean microbial counts (cfu/ml) with corresponding mean $\log _{10} \mathrm{cfu} / \mathrm{ml}$ of beef

Mean bacterial and fungal counts, cfu/ml, of beef (mean $\log _{10}$ cfu/ml); $n=6$

\section{Markets}

$\begin{array}{lll}\text { Abura } & \text { Kotokuraba } & \text { Science }\end{array}$

Culture medium

\begin{tabular}{|c|c|c|c|}
\hline *Nutrient agar & $4.50 \times 10^{7} \quad(7.65)$ & $1.15 \times 10^{8}$ & $1.05 \times 10^{8} \quad(8.02)$ \\
\hline *MacConkey agar & $1.90 \times 10^{7}$ & $9.40 \times 10^{7}$ & $7.80 \times 10^{7} \quad(7.89)$ \\
\hline $\begin{array}{l}* * \text { Potato } \\
\text { agar }\end{array}$ & $8.00 \times 10^{3}(3.90)$ & $1.60 \times 10^{4}$ & $2.00 \times 10^{3}$ \\
\hline
\end{tabular}

* Bacterial counts; ** Fungal counts 
Table 2. Mean microbial counts (cfu/ml) with corresponding mean $\log _{10} \mathrm{cfu} / \mathrm{ml}$ of chevon

Mean bacterial and fungal counts, cfu/ml, of chevon (mean $\left.\log _{10} \mathrm{cfu} / \mathrm{ml}\right) ; \mathrm{n}=6$

\section{Markets}

Abura Kotokuraba Science

\section{Culture medium}

\begin{tabular}{lcccc}
\hline *Nutrient agar & $8.80 \times 10^{7}(7.94)$ & $9.00 \times 10^{7}$ & $(7.95)$ & $1.67 \times 10^{8} \quad(8.22)$ \\
\hline *MacConkey agar & $4.00 \times 10^{7}(7.60)$ & $5.70 \times 10^{7} \quad(7.76)$ & $7.10 \times 10^{7} \quad(7.85)$ \\
\hline **Potato dextrose agar & $4.40 \times 10^{4}(4.64)$ & $1.00 \times 10^{3}$ & $(3.00)$ & $4.30 \times 10^{4} \quad(4.63)$ \\
\hline
\end{tabular}

* Bacterial counts; ** Fungal counts

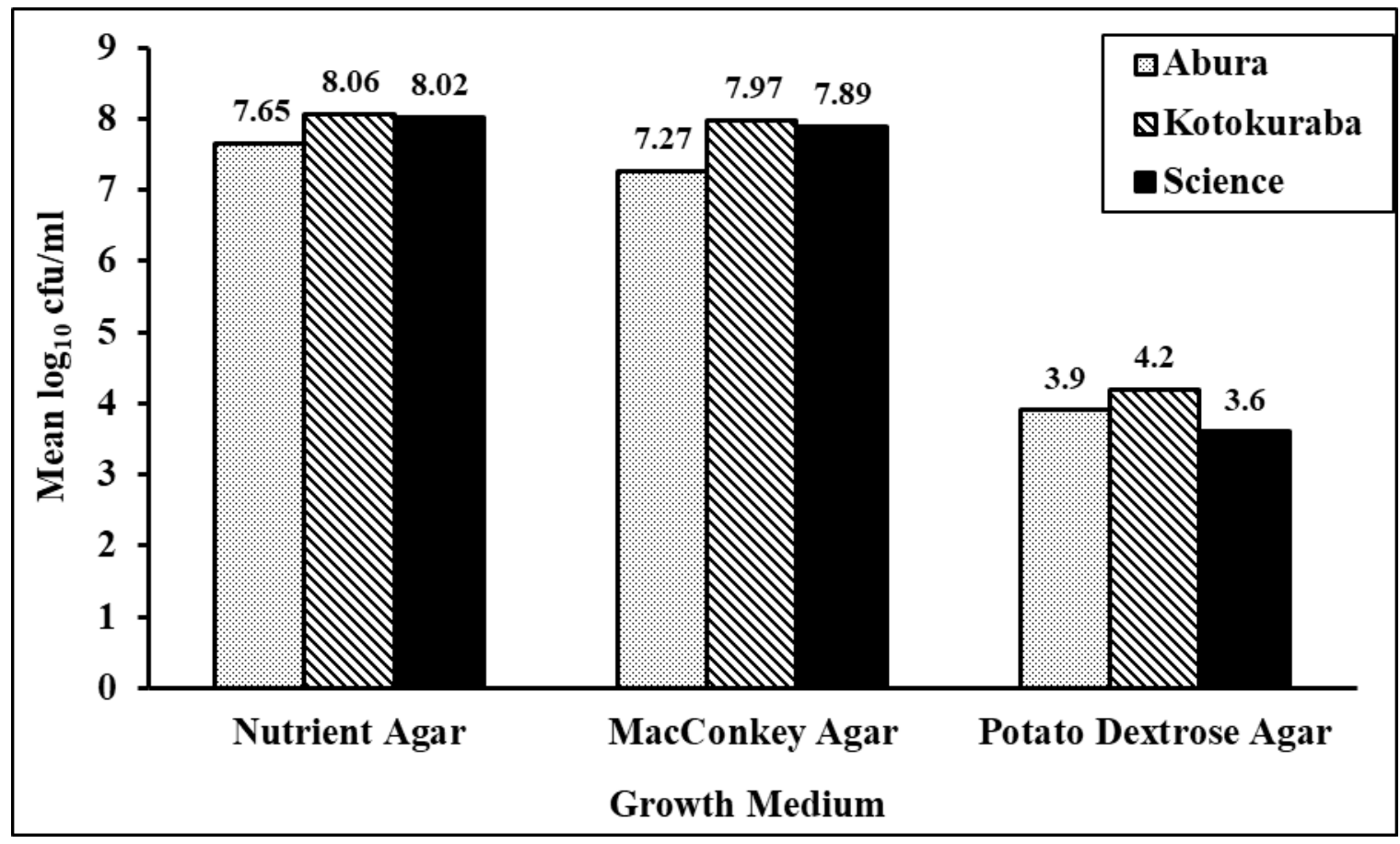

Figure 3. Mean $\log _{10} \mathrm{cfu} / \mathrm{ml}$ of bacteria and fungi isolated from beef from Abura, Kotokuraba and Science markets in Cape Coast 


\section{MInstitute ${ }^{\text {Mnk }}$}

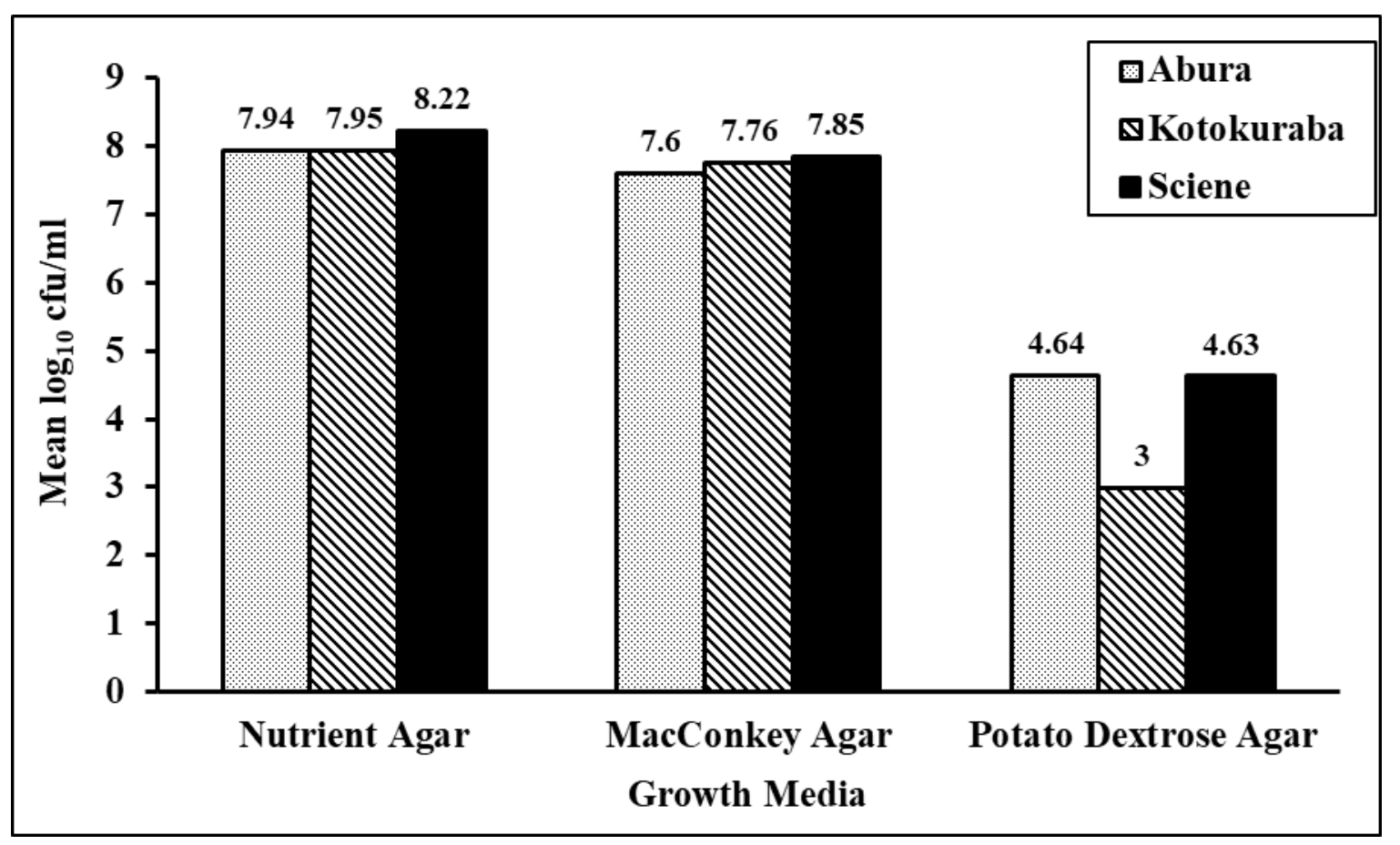

Figure 4. Mean $\log _{10} \mathrm{cfu} / \mathrm{ml}$ of bacteria and fungi isolated from chevon obtained Abura, Kotokuraba and Science markets in Cape Coast

\subsection{Identification of Isolated Bacteria and Fungi}

Identification procedures revealed that beef and chevon were contaminated with bacteria such as Escherichia coli, and Klebsiella spp., Nocardia spp., Salmonella spp., Staphylococcus spp., and Streptococcus spp. Fungi isolated and confirmed from both beef and chevon are of the genera Aspergillus, Candida, Fusarium, Penicillium, and Rhodotorula (Plate 1 and Plate 2).

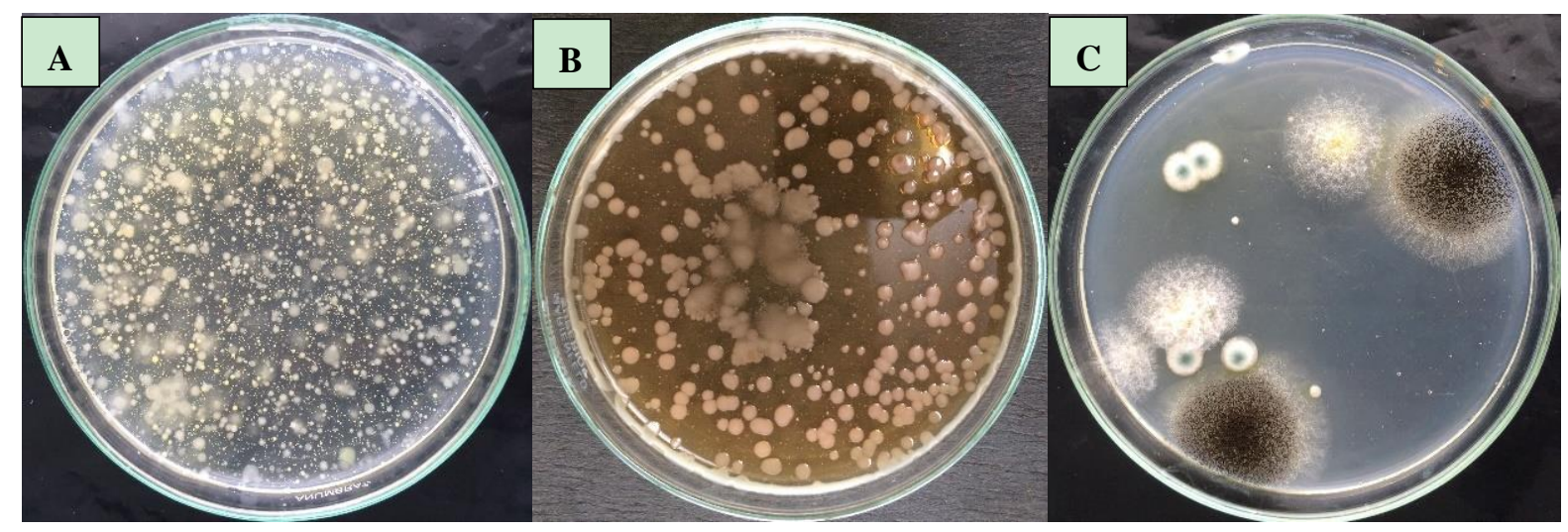

Plate 1. Bacteria and fungi isolated from beef on nutrient agar medium (A), MacConkey agar medium (B), and potato dextrose agar medium (C) 


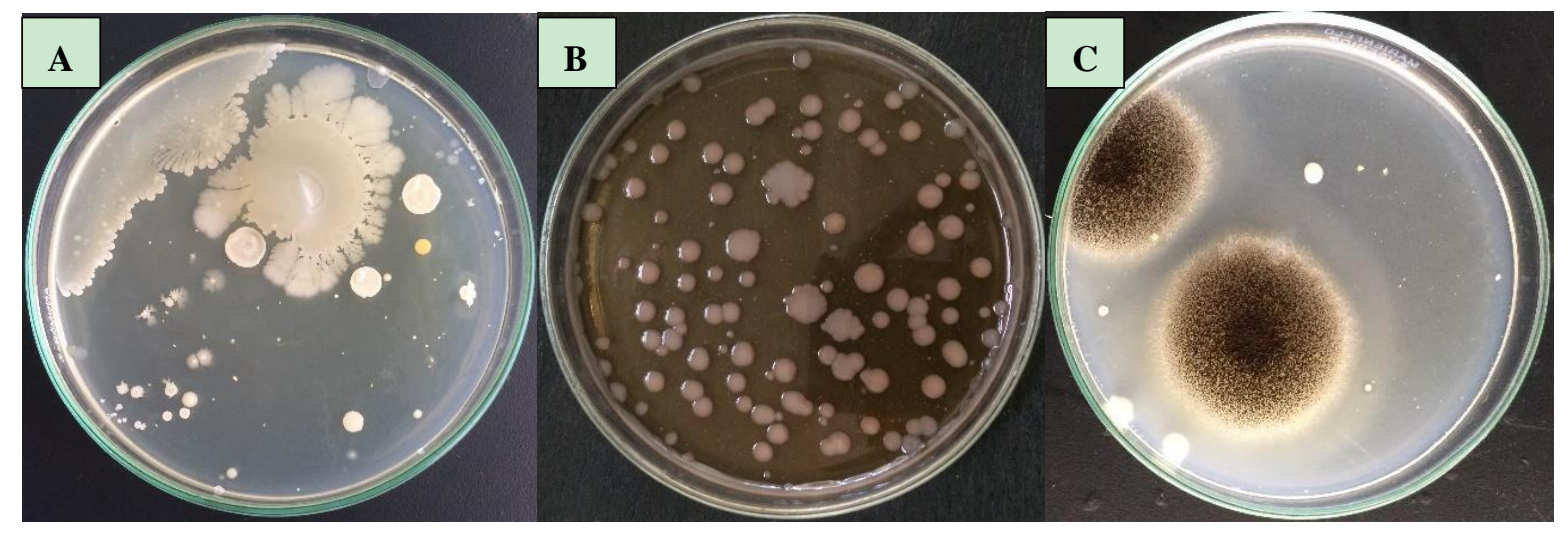

Plate 2. Bacteria and fungi isolated from chevon on nutrient agar medium (A), MacConkey agar medium (B) and potato dextrose agar medium (C)

\section{Discussion}

Findings from this study revealed that beef from Kotokuraba market was the most contaminated, whereas chevon from Science market was the most contaminated (Table 1, Table 2, Figure 3 and Figure 4). Interestingly, findings from this study indicate higher bacterial counts that had contaminated beef and chevon compared to findings by Adejunmobi (2015).

This study further revealed that raw beef and chevon obtained from the various meat retail shops in the selected markets in Cape Coast are contaminated with both bacteria - E. coli, Klebsiella spp., Nocardia spp., Salmonella spp., Staphylococcus spp., and Streptococcus spp. Adejunmobi (2015) in a preliminary study reported that beef and chevon obtained from Kotokoraba market in Cape Coast were mostly contaminated by E. coli, Salmonella spp. and Shigela spp., and further suggested that the beef and chevon were of poor microbial quality with serious health implications to consumers.

Studies conducted on meat and other meat products in Ghana reported high microbial counts, just as this study, and further confirmed the presence of varying pathogenic, toxigenic bacteria - E. coli, Bacillus spp., Enterococcus spp. Diplococci spp., Micrococcus spp., Salmonella spp., Staphylococcus spp., Streptococcus spp. (Adzitey et al., 2010; Adzitey et al., 2011b; Adzitey et al., 2014; Ansah et al., 2009; Iddrisu, 2007; Kutah, 2010; Obeng et al., 2013). Surprisingly, Klebsiella spp., and Nocardia spp. reported in this study, and Shigella reported by Adejunmobi (2015) were not reported by studies aforementioned. This may suggest that Klebsiella spp., Nocardia spp. and Shigella spp. may be endemic to Cape Coast and localized to beef and chevon in Cape Coast. This conjecture may largely be supported by Adu-Gyamfi et al. (2012) and Twum (2015) who reported E. coli, Salmonella spp. and Staphylococcus spp. from chicken and beef sold in Accra, the Capital city of Ghana, and Birim North District in the Eastern Region of Ghana, respectively. Interestingly, bacteria such as Enterococcus spp., Diplococcus spp., Micrococcus spp. were not isolated from beef and chevon in Cape Coast, a finding which may equally suggest that these bacterial species may 
be endemic to those geographical locations from which the meat samples were obtained and assessed for microbial contamination.

Similar studies conducted in other countries to assess microbial quality of meat reveal the presence of bacteria also reported by this study. In addition to high microbial counts, these studies further reported that the most common microbes isolated from meats are bacterial pathogens such as Bacillus spp., Clostridium spp., Campylobacter spp., E. coli, Listeria spp., Pseudomonas spp., Salmonella spp., Shigella spp., Staphylococcus spp. and Yersinia spp. (Ali et al., 2010; Alvarez-Astorga et al., 2002; Biswas et al, 2011; Borch et al., 1996; Ceruti et al., 2003; Colmegna et al., 2009; Huang et al. 2014; Koffi-Nevry et al., 2011; Kozačinski et al., 2006; Lindblad et al., 2006; Mukhopadhyay et al., 1998; Mukhopadhyay et al., 2009; Selvan et al., 2007; Vural et al., 2006; Zhao et al., 2001). Borch et al., (1996) specifically identified Brochotrix thermosphacta, Carnobacterium spp., Enterobacteriaceae, Lactobacillus spp., Pseudomonas spp., and Shewanella putrefaciens as the predominant bacteria associated with spoilage of refrigerated beef and pork. Isolation of these bacteria species around the world suggests that, indeed, meat products are highly prone to microbial contaminations, presenting them as a potential source of foodborne illnesses to consumers.

A diversity of fungal genera was isolated from beef and chevon that were sampled in this study, namely, Aspergillus, Candida, Fusarium, Penicillium, and Rhodotorula. Interestingly, Annan-Prah et al. (2011) conducted a study to assess the microbial quality of street-foods in Cape Coast and revealed that, in addition to the isolation of E. coli, which was of faecal origin, and present in all the street-foods sampled, the following major fungi were present: Aspergillus flavus, Aspergillus candidus, Aspergillus niger, Cladosporium herbarum, Neurospora crassa, Penicillium citrinum, Fusarium spp., Mucor spp., Rhizopus spp. and yeasts. Ismail et al., (1995) also reported the presence of Aspergillus spp., Cladosporium spp. and Penicillium spp. from beef and environments of a slaughterhouse. Adejunmobi (2015) and Annan-Prah et al. (2011) isolated yeasts from street-foods, and beef and chevon respectively, but they did not conclusively identify them, unlike this study which conclusively identified Candida and Rhodotorula. Interestingly, Tawakkol and Khafaga (2011) also confirmed the presence of Aspergillus, Candida, Penicillium, and Rhodotorula from meat samples obtained during slaughter and from the butcher shops. These fungi tested for the production of mycotoxins, whereas others had proteolytic and lipolytic activities. The compendium of activities by the diverse fungi in the midst of pathogenic bacteria gravely affect the quality - colour, taste, and odour - of meats (Griffiths et al., 1981). Thus, over time, the effects of microbial action on meat will lead to meat spoilage and poisoning, consequently making them unwholesome for consumption and potential sources of foodborne illnesses.

Observations during this study suggest that there is a general disregard to best practices of personal and environmental hygiene by butchers and retailers in Cape Coast. In most meat retail shops, beef and chevon carcasses were openly butchered in the open, on bare floors, wooden slaps or card boxes that are hardly tidied. In cases where the floor or the wooden slabs were cleaned, it was further observed that (i) water used to clean the beef and chevon are those that had been previously used to clean other carcasses in the early hours of the day, 
(ii) most of the knives, weighing scales, and other equipment used by the butchers and retailers were not properly cleaned and sanitized, (iii) most butchers and retailers were not properly clothed while they sell meat to customers, and (iv) butchers and retailers concurrently handled money and meat with bare hands while they serve customers. It is therefore not surprising that we isolated substantially high microbial levels of microbes and further identified some of the well-known pathogenic and toxigenic microbes from beef and chevon we obtained for this study, results which are comparable to those reported by studies in other parts of Ghana (Adejunmobi 2015; Adu-Gyamfi et al. 2012; Annan-Prah et al. 2011; Adzitey et al. 2010; Adzitey et al. 2014; Ansah et al. 2009; Chepkemoi, 2016; Iddrisu 2007; Kutah 2010; Obeng, et al. 2013; Twum 2015).

Contaminations of meat sampled for this study may occur from two major sources, namely, primary and secondary sources: primary source of contamination may be as a result of activities of animals that include, but not limited to, secretion and excretion, whereas secondary source of contamination may stem from infected humans, contaminated water and equipment, and poor pre- and post-slaughter handling of animals (Marriot, 2004). There is therefore a certainty that the beef and chevon were contaminated at the time when even healthy animals were slaughtered and eviscerated at the abattoir or at the meat retail shops. These notwithstanding, there is also the possibility that (i) the slaughtered animals may have been contaminated with potential pathogenic and spoilage bacteria that resided in the hide, gastrointestinal and respiratory tract and (ii) the animals slaughtered and eviscerated on the floor had a high risk of bacterial contamination (Sofos et al., 1999). It suffices to suggest then that the types of microbial contamination and the extent of spoilage of meats depend largely on sanitation procedures and hygienic practices employed during meat handling, processing, transportation, distribution, and storage, which invariably may have damning implications for public health (Adu-Gyamfi et al., 2012; Ercolini et al., 2006; Komba et al., 2012; Kivi et al., 2007; Li et al., 2006). High-risk populations, such the populous southern communities of Cape Coast, can be identified through surveillance for risky food-handling and food-consumption practices, which will subsequently aid in the development of educational efforts, and evaluation of progress towards risk reduction (Altekruse, et al., 1999). This is critical in the pursuit and promotion of measures that inure to the benefit of the vibrant, robust hospitality and tourism industry in Cape Coast.

\section{Conclusions}

We conclude, based on findings from this study that, beef and chevon sold on markets in Cape Coast, Ghana, are contaminated with microbes - bacteria and fungi. We further conclude that bacterial contaminations of both beef and chevon are higher than fungal contaminations. The presence of these microbes and their activities are a cause for concern since they may be pathogenic, toxigenic, and consequently cause foodborne illnesses to consumers. Observations made from the meat retail shops where chevon and beef were obtained for this study suggest that microbial contaminations of these meat products may be as a result of (i) improper and/or unhygienic handling of meat by both butchers and retailers during dressing and transportation, (ii) poor sanitary conditions at the abattoirs and meat retail stores, and (iii) contaminated water used to dress slaughtered animals at the abattoirs, 
and even at the meat retail stores. Findings from this study add to existing literature and further expand knowledge about contaminated foods, particularly meat products on the Ghanaian market and their potential to cause foodborne illnesses. It is therefore recommended that (i) butchers, retailers and consumers observe good personal and environmental hygiene and sanitation practices; (ii) best practices of pre- and post-animal handling by butchers and retailers should be observed, (iii) consumers must cook fresh meat well before consumption, and (iv) strict enforcement of inspection of abattoirs and meat retail stores by the country's regulatory bodies such as Foods and Drugs Authority and Ghana Standards Authority must be pursued to the letter. This study provides more opportunities for further investigations to elucidate the extent of food safety risks associated with microbial contaminations of meat products as well as fruits, vegetables and cooked street foods sold by retailers in the Cape Coast, Ghana.

\section{Acknowledgements}

The authors thank Messrs. Solomon Mensah, George Koomson, and Albert Ofosuhene, Department of Molecular Biology and Biotechnology, University of Cape Coast, Ghana, for providing technical assistance during the study. We are grateful also to Mr. Richard Adade, Centre for Coastal Management, University of Cape Coast, for providing the map of Cape Coast.

\section{References}

Ababio, P. F., \& Lovatt, P. (2015). A review on food safety and hygiene studies in Ghana. Food Control, 47, 92-97. https://doi.org/10.1016/j.foodcont.2014.06.041

Adejunmobi, A. M. (2015). Microbial quality of meat from the Kotokuraba meat market, Cape Coast, Ghana. B.Sc. Dissertation. University of Cape Coast, Cape Coast, Ghana.

Adu-Gyamfi, A., Torgby-Tetteh, W., \& Appiah, V. (2012). Microbiological quality of chicken sold in Accra and determination of D10-Value of E. coli. Food Nutrition Science, 3(5), 693-698. https://doi.org/10.4236/fns.2012.35094

Adzitey, F. (2013). Animal and meat production in Ghana - An overview. The Journal of World's Poultry Research, 3, 1-4.

Adzitey, F., Abdul-Aziz, A., \& Moses, O. (2014). Microbial quality of beef in the Yendi Municipality of Ghana. Global Journal of Animal Scientific Research, 2, 10-17.

Adzitey, F., Teye, G. A., \& Dinko, M. M. (2011a). Pre- and post-slaughter animal handling by butchers in the Bawku Municipality of the Upper East Region of Ghana. Livestock Research for Rural Development, 23, Article \# 39.

Adzitey, F., Teye, G. A., Ayim, A. G., \& Addy, S. (2010). Microbiological quality of chevon and mutton sold in Tamale Metropolis of Northern Ghana. Journal of Applied Sciences and Environmental Management, 14(4), 53-55.

Adzitey, F., Teye, G. A., Kutah, W. N., \& Adday, S. (2011b). Microbial quality of beef sold on selected markets in the Tamale Metropolis in the Northern Region of Ghana. Livestock 
Research for Rural Development, 23, Article \# 5.

Ali, N. H., Farooqui, A., Khan, A., Khan, A. Y., \& Kazmi, S. U. (2010). Microbial contamination of raw meat and its environment in retail shops in Karachi, Pakistan. Journal of Infection in Developing Countries, 4(6), 382-388.

Altekruse, S. F., Yang, S., Timbo, B. B., \& Angulo, F. J. (1999). A multi-state survey of consumer food-handling and food consumption practices. American Journal of Preventive Medicine, 16(3), 216-221. https://doi.org/10.1016/S0749-3797(98)00099-3

Alvarez-Astorga, M., Capita, R., Alonso-Callega, C., Moreno, B., Del, M., \& Garcia-Fernandez, C. (2002). Microbiological quality of retail chicken by-products in Spain. Meat Science, 62(1), 45-50. https://doi.org/10.1016/S0309-1740(01)00225-X

Annan-Prah, A., Amewowor, D. H. A. K., Osei-Kofi, J., Amoono, S. E., Akorli, S. Y., Saka, E., \& Ndadi, H. A. (2011). Street foods: handling, hygiene and client expectations in a World Heritage Site Town, Cape Coast, Ghana. African Journal of Microbiology Research, 5(13), 1629-1634. https://doi.org/10.5897/AJMR11.199

Annor-Frimpong, I., \& Danquah, G. (1994). Meat consumption pattern in the Central and Western Region of Ghana. Conference proceedings of the $2^{\text {nd }}$ Animal Science Society, Cape Coast, Ghana.

Ansah, T., Dzoagbe, G. S. K., Teye, G. A., Adday, S., \& Danquah, J. K. (2009). Microbial quality of table eggs sold on selected markets in the Tamale Municipality in the Northern Region of Ghana. Livestock Research for Rural Development, 21(8).

Ateba, C. N., \& Setona, T. (2011). Isolation of enteric bacterial pathogens from raw meat in Mafikeng, North-West Province. South Africa. Life Science Journal, 8(S2), 1-7.

Barnett, H. L., \& Hunter, B. B. (1995) Illustrated genera of fungi imperfecti. Scotland, UK: Burgess.

Biswas, A. K., Kondaiah, N., Anjaneyulu, A. S. R., \& Mandal, P. K. (2011). Cause, concern, consequences and control of microbial contaminants in meat - A review. International Journal of Meat Science, 1(1), 27-35. https://doi.org/10.3923/ijmeat.2011.27.35

Borch, E., Kant-Muermans, M. L., \& Blixt, Y. (1996). Bacterial spoilage of meat and cured meat products. International Journal of Food Microbiology, 33, 103-120. Abstract retrieved from the https://doi.org/10.1016/0168-1605(96)01135-X

Bradeeba, K., \& Sivakumaar, P. K., (2012). Assessment of microbiological quality of beef, mutton and pork and its environment in retail shops in Chidambaram, Tamil Nadu. International Journal of Plant, Animal and Environmental Sciences, 3(1), 91-97.

Bryan, F. L. (1977). Diseases transmitted by foods contaminated by wastewater. Journal of Food Protection, 40, 45-56. https://doi.org/10.4315/0362-028X-40.1.45

Campbell, C. K., Johnson, E. M., \& Warnock, D. W. (2013). Identification of pathogenic fungi. (2nd ed.). London, UK: Wiley-Blackwell. https://doi.org/10.1002/9781118520055 


\section{Macrothink}

Centers for Disease Control and Prevention (2016). Surveillance for Foodborne Disease Outbreaks, United States: 2016, Annual Report. Atlanta, Georgia: U.S. Department of Health and Human Services, CDC, 2018. Retrieved from

https://www.cdc.gov/fdoss/pdf/2016_FoodBorneOutbreaks_508.pdf

Ceruti, R., Gavazzi, L., Manarolla, G., Stonfer, M., Gallazzi, D., \& Grilli, G. (2003). Salmonella spp. in broiler flocks and hatcheries in northern Italy: 2 years of bacteriological monitoring. Page 120 in Proceedings of the $52^{\text {nd }}$ Western Poultry Disease Conference, Sacramento, CA, USA.

Chepkemoi, S. (2016), Handling practices, microbial quality and weight loss of beef in small and medium enterprise butcheries in Nairobi and Isiolo counties, Kenya. Masters Dissertation. University of Nairobi, Kenya.

Colmegna, S., Invernizzi, A., Mascher, A. L., Corsale, E., Ferrazi, V., \& Grilli, G. (2009). Microbiological characteristics of poultry meats - results of inspections carried out in the province of Milano, Italy. Italian Journal of Animal Science, 8(4), 765-770.

https://doi.org/10.4081/ijas.2009.765

Courtecuisse, R., \& Duhem, B. (1995). Mushrooms and Toadstools of Britain and Europe. Collins Field Guide. London: Harper Collins Publishers, 480.

Eaton, S. B., \& Konner, M. (1985). Paleolithic nutrition. A consideration of its nature and current implications. New England Journal of Medicine, 312, 228-289.

https://doi.org/10.1056/NEJM198501313120505

Ellis, D., Davis, S., Alexiou, H., Handke, R., \& Bartley, R. (2007). Descriptions of medical fungi. (2nd ed.). Adelaide, Australia.

Ercolini, D., Russo, F., Torrieri, E., Masi, F., \& Villani, F. (2006). Changes in the spoilage-related microbiota of beef during refrigerated storage under different packaging conditions. Applied Environmental Microbiology, 72, 4663-4671.

https://doi.org/10.1128/AEM.00468-06

Food and Agriculture Organization. (2016). Street food in urban Ghana: A desktop review and analysis of findings and recommendations from existing literature. [Marras, S., \& Ag Bendech, M. (Eds)]. Accra, Ghana: Food and Agriculture Organization. Retrieved from http://www.fao.org/3/a-i5804e.pdf

Ghana Statistical Services (2010). Population and Housing Census, District Analytical Report. Retrieved from http://www.statsghana.gov.gh/docfiles/2010_District_Report/Central/Cape\%20Coast.pdf Gilbertson, R. L., \& Ryvarden, L. (1986). North American Polypores. Fungiflora, Oslo. Griffiths, M. W., Phillips, J. D., \& Muir, D. D. (1981). Thermostability of proteases and lipases from a number of species of psychrotrophic bacteria of dairy origin. Journal of Applied Bacteriology, 50, 289-303. https://doi.org/10.1111/j.1365-2672.1981.tb00894.x 
Hobbs, B. C., \& Roberts, D. (1993). Food poisoning and food hygiene. (6th ed.). [Mclauchlin, J., \& Little, C. (Eds)]. London: Hodder Arnold.

Huang, R., Dawson, C. O., \& Hussain, M. A. (2014). Microbiological quality of selected meat products in the Canterbury Region of New Zealand. Internet Journal of Food Safety, 16, 12-16.

Huda, N., Shen, Y. H., Huey, Y. L., Ahmad, R., \& Mardia, A. (2010). Evaluation of physico-chemical properties of Malaysian commercial beef meatballs. American Journal of Food Technology, 5, 13-21. https://doi.org/10.3923/ajft.2010.13.21

Iddrisu, Y. (2007). Bacterial quality of locally produced milk and cheese in Peri-Urban areas in Tamale Metropolis.

Ismail, M. A., Abou Elala, A. H., Nassar, A., \& Michail, D. G. (1995). Fungal contamination of beef carcasses and the environment in a slaughterhouse. Food Microbiology, 12, 441-445. Abstract retrieved from https://doi.org/10.1016/S0740-0020(95)80128-6

Kidd, S., Halliday, C., Alexiou, H., \& Ellis, D. (2016). Descriptions of Medical Fungi (3rd ed.). Adelaide, Australia: Newstyle Printing.

King, L. K, Awumbila, B., Canacoo, E. A., \& Ofosu-Amaah, S. (2000). An assessment of the safety of street foods in the Ga District of Ghana; implications for the spread of zoonoses. Acta Tropica, 76(1), 39-43. https://doi.org/10.1016/S0001-706X(00)00087-5

Kivi, M., Hofhuis, A., Notermans, D. W., Wannet, W. J., Heck, M. E., et al. (2007). A beef-associated outbreak of Salmonella typhimurium DT104 in the Netherlands with implications for national and international policy. Epidemiology and Infection, 135, 890-899. https://doi.org/10.1017/S0950268807007972

Koffi-Nevry, R., Koussémon, M., \& Coulibaly, S. O. (2011). Bacteriological quality of beef offered for retail sale in Cote d'Ivoire. American Journal of Food Technology, 6(9), 835-842. https://doi.org/10.3923/ajft.2011.835.842

Komba, E. V., Mkupasi, E. M., Mbyuzi, A. O., Mshamu, S., Luwumba, D., Busagwe, Z., \& Kozačinski, L., Hadažiosmanović, M., \& Zdolec, N. (2006). Microbiological quality of poultry meat on the Croatian market. Veterinarski Arhiv, 76(4), 305-313.

Kutah, W. N. (2010). Microbial quality of beef in selected meat shops in the Tamale Metropolis. B.Sc. Dissertation. University of Development Studies, Tamale, Ghana.

Læssøe, R. (1998). Mushrooms (Eyewitness Handbooks). London: Dorling Kindersley Book.

Li, M, Y., Zhou, G. H., Xu, X. L., Li, C. B., \& Zhu, W. Y. (2006). Changes of bacterial diversity and main flora in chilled pork during storage using PCR-DGGE. Food Microbiology, 23(7), 607- 611. https://doi.org/10.1016/j.fm.2006.01.004

Lindblad, M., Lindmark, H., Lambertz, S. T., \& Lindqvist, R. (2006). Microbiological baseline study of broiler chickens at Swedish slaughterhouses. Journal of Food Protection, 69, 2875-2882. https://doi.org/10.4315/0362-028X-69.12.2875 


\section{Macrothink}

Journal of Biology and Life Science ISSN 2157-6076 2019, Vol. 10, No. 1

Mahaboubil-Haq, M., \& Adzitey, F. (2016). Meat production and consumption in the Wa Municipality of Ghana. International Food Research Journal, 23(3), 1338-1342.

Marriott, J. A. (2004). Microbial problems in handling and storage of fresh meats. Journal of Applied Bacteriology, 7, 433-441.

Mensah P., Armar-Klemesu M., Hammond A. S., Haruna A., \& Nyarko R. (2001). Bacterial contaminants in lettuce, tomatoes, beef and goat meat from metropolitan Accra. Ghana Medical Journal, 35, 1-6.

Mukhopadhyay, H. K., Pillai, R. M., Pal, U. K., \& Kumarm, V. J. A. (2009). Microbial quality of fresh chevon and beef in retail outlets of Pondicherry. Tamilnadu Journal of Veterinary and Animal Sciences, 5(1), 33-36.

Mukhopadhyay, H. K., Puvarajan, B., \& Dorairajan, N. (1998). Detection of microbial load in fresh mutton and its implication to public health. Indian Journal of Animal Health, 37, 81-83.

Mzula, A. (2012). Sanitary practices and occurrence of zoonotic conditions in cattle at slaughter in Morogoro Municipality, Tanzania: Implications for Public Health. Tanzania Journal of Health Research, 14 (2), 131-8.

Nel, S., Lues, J. F. R., Buys, E. M., \& Venter P. (2004). Bacterial populations associated with meat from the deboning room of a high throughput red meat abattoir. Meat Science, 66, 667-674. https://doi.org/10.1016/S0309-1740(03)00187-6

Obeng, A. K., Johnson, F. S., \& Appenteng, S. O. (2013). Microbial quality of fresh meat from retail outlets in Tolon and Kumbungu Districts of the Northern Region of Ghana. International Journal of Science and Technology, 2(6), 423-428.

Overholts, L. O. (1953). The Polyporaceae of the United States, Alaska and Canada. Ann. Arbor, Michigan: University of Michigan Press, 466.

Pegler, D. N. (1977). A preliminary agaric flora of East Africa. Kew Botanical Additional Series, 6, 1-615.

Phillips, R. (1981). Mushrooms and other fungi of Great Britain and Europe. London, Pan Books Ltd., 287.

Pitt, J. I., \& Hocking, A. D. (2009). Fungi and food spoilage. (3rd ed.). New York: Springer. https://doi.org/10.1007/978-0-387-92207-2

Ryvarden, L., \& Johansen, I. (1980). A Preliminary Polypore Flora of East Africa. Fungiflora, Oslo

Scallan, E., Hoekstra, R. M., Angulo, F. J., et al. (2011). Foodborne illness acquired in the United States-major pathogens. Emerging Infectious Diseases, 17(1), 7-15. https://doi.org/10.3201/eid1701.P11101

Selvan, P., Narendra, B. R., Sureshkumar, S., \& Venkataramanujam, V. (2007). Microbial quality of retail meat products available in Chennai City. American Journal of Food 
Technology, 2, 55-59. https://doi.org/10.3923/ajft.2007.55.59

Sofos, J. N., Belk, K. E., \& Smith, G. C. (1999). Processes to reduce contamination with pathogenic microorganisms in meat. Proceedings of the 45th International Congress of Meat Science and Technology, Yokohama, Japan. 596-605.

Soriyi, I., Agbogli, H. K., \& Dongdem, J. T. (2008). A pilot microbial assessment of beef sold in the Ashaiman market, a suburb of Accra, Ghana. African Journal of Food, Agriculture, Nutrition and Development, 8(1), 91-103. https://doi.org/10.4314/ajfand.v8i1.19182

Steinkraus, K. H. (1994). Nutritional significance of fermented foods. Foods Research International, 27, 259-267. https://doi.org/10.1016/0963-9969(94)90094-9

Stufflebeam, E. C. (1983). Meat and Wool. Principle of Animal Agriculture. USA: Prentice Hall, pp. 312-341.

Subratty, A. H., \& Gurib, F. B. H. (2003). Consumer's concern about meat and meat products quality offered for sale in Mauritius. Nutrition and Food Science, 33, 80-83. https://doi.org/10.1108/00346650310466664

Tawakkol, W., \& Khafaga, N. I. (2007). Fungal contamination of meat and its environment with special reference to the strains producing aflatoxins, ochratoxins, proteinase and lipase enzyme. New Egyptian Journal of Microbiology, 17(2), 1-14. Abstract retrieved from the https://doi.org/10.4314/nejmi.v17i1.40310

Tomlins, K. I., Johnson, P-N. T., Aseidu, O. P., Myhara, B., \& Greenhalgh, P. (2002). Street food in Ghana: A source of income, but not without hazards. PH Action News, the Newsletter of the Global Post-Harvest Forum, No. 5, March 2002.

Twum, E. (2015). Microbial quality offresh beef sold in the Birim North District of the Eastern Region of Ghana. Masters Dissertation. Kwame Nkrumah University of Science and Technology, Kumasi, Ghana.

van der Westhuizen, G. C. A., \& Eicker, A. (1994). Mushrooms of Southern Africa Field Guide. Cape Town: Struik Publishers (Pty) Ltd.

Vural, A., Erkan, M. E., \& Yesilmen, S. (2006). Microbiological quality of retail chicken carcasses and their products in Turkey. Medycyna Weterynaryijna, 62, 1371-1374.

Watanabe, T. (2010). Pictorial atlas of soil and seed fungi; morphologies of cultured fungi and key to species. (3rd ed.). New York: CRC Press. https://doi.org/10.1201/EBK1439804193

World Health Organization. (2015). WHO estimates of the global burden of foodborne diseases. A report by the Foodborne Disease Burden Epidemiology Reference Group 2007-2015. Geneva, Switzerland.

Yafetto, L., \& Osei-Bonsu, V. (2017). Ethnomycological survey of Cape Coast Metropolis, Ghana. Current Research in Environmental and Applied Mycology, 7(4), 258-366. https://doi.org/10.5943/cream/7/4/2 


\section{Macrothink}

Yeboah-Manu, D., Kpeli, G., Akyeh, M., \& Bimi, L. (2010). Bacteriological quality of ready-to-eat foods sold on and around University of Ghana campus. Research Journal of Microbiology, 5(2), 130-136. https://doi.org/10.3923/jm.2010.130.136

Yeleliere, E., Cobbina, S. J., \& Abubakari, Z. I. (2017). Review of microbial food contamination and food hygiene in selected capital cities in Ghana. Cogent Food and Agriculture, 3(1). https://doi.org/10.1080/23311932.2017.1395102

Yousuf, A. H. M., Ahmed, M. K., Yeasmin, S., Ahsan, N., Rahman, M. M., \& Islam, M. M. (2008). Prevalence of microbial load in shrimp, Penaeus monodon and prawn, Macrobrachium rosenbergii from Bangladesh. World Journal of Agricultural Sciences, 4, 852-855.

Zhao, C., Ge, B., De Villena, J., Sudler, R., Yeh, E., Zhao, S., ... Meng, J. (2001). Prevalence of Campylobacter spp., Escherichia coli, and Salmonella serovars in retail chicken, turkey, pork and beef from the greater Washington, D.C. area. Applied and Environmental Microbiology, 67(12), 5431-5436. https://doi.org/10.1128/AEM.67.12.5431-5436.2001

\section{Copyright Disclaimer}

Copyright for this article is retained by the author(s), with first publication rights granted to the journal.

This is an open-access article distributed under the terms and conditions of the Creative Commons Attribution license (http://creativecommons.org/licenses/by/3.0/). 